\title{
Microstructural evolution in friction stir welded API 5L-X52 steel
}

\author{
Ehsan Gharibshahiyan", Abbas Honarbakhsh Raouf ${ }^{2}$, Nader Parvin ${ }^{3}$ \\ MSc in Materials Science and Engg., Faculty of Materials and Metallurgy Engg., Semnan University, Iran ${ }^{1}$ \\ Associate Professor, Faculty of Materials and Metallurgy Engineering, Semnan University, Iran ${ }^{2}$ \\ Associate Professor, Faculty of Mining and Materials Engineering, Amirkabir University of Technology (AUT), \\ Hafez Ave, Tehran, $\operatorname{Iran}^{3}$
}

\begin{abstract}
Welded API-5L steel pipes have been extensively used in the oil industry. One of the major parameters affecting the mechanical properties is the grain size, which is altered with the joining method. In this paper microstructural evolution in the friction stir welded API 5L-X52 steel pipes has been investigated.Specimens were cut from a $2 \mathrm{~mm}$ thick API 5L-X52 steel pipe. The steel sheets were then joined by friction stir welding process; at a linear speed of $100 \mathrm{~mm} / \mathrm{min}$. The tool rotational speed was varied from 400 to $800 \mathrm{rpm}$. Samples were then evaluated using tensile test, metallographic and hardness measurements. Microstructural investigations revealed the stir zone, heat affected zone and thermo mechanically affected zones. Heat input in the stir zone led to the formation of elongated austenite grains which were transformed to fine ferrite and pearlite grains and widmanstatten ferrite in certain regions. Plastic deformation and recrystallization enhanced the hardness and tensile strength as well as toughness of the welded joint in the API 5L-X52 steel.
\end{abstract}

Keywords: Friction stir welding, API 5L-X52 steel, microstructure, ferrite and pearlite grains.

\section{INTRODUCTION}

Friction stir welding (FSW) has been well established for with high SFE, such as ferritic stainless steel undergo low melting point metals and alloys. Recently, extensive recrystallization. applications have been extended to high temperature materials such as stainless steel, titanium and nickel alloys [1-8].

Public concern on the utilization of renewable energy has had its impact on welding technology in the oil industry [9]. API-5L pipes have been used to transfer petroleum products [10]. Conventional welding techniques normally generate changes in physical and mechanical properties of the pipes which can raise maintenance costs. Recent researches reveal that friction stir welding (FSW) method can compensate for the shortcomings of the conventional processes. However, a clear understanding of the effect of processing parameters in ferrous alloys has been a matter of conjecture [11, 12-13].

Sato et al [11], welded high carbon steel pipes by FSW, and observed twin ferrite - cementite and martensite in the stir zone. Cho et al [12] joined 409 stainless steel specimens and reported that severe plastic deformation led to the generation of fine grains, low angle grain boundaries, and high hardness in the weld metal. In another research Sato [14] found that the grain size of the stir zone of SAF 2507 was smaller than that of the base metal. He concluded that dynamic recrystallization can readily occur in austenitic stainless steel, whereas this phenomenon is not the case in ferritic steels. The dominating mechanism depends on the strain rate and stacking fault energy (SFE). Materials with a low SFE, such as austenitic stainless steel, experience a discontinuous recrystallization since dislocations may hinder the recovery procedure. On the other hand materials
Ozekchin [15] carried out extensive research on FSWed API-5LX80 steel and reported the grain size about 5 and 30 microns in HAZ and TMAZ respectively, in the form of bainite together with martensite. It has also been illustrated that promising results can be obtained for stainless steel [16, 17-18] and carbon steels [19-20].

Nowadays, API 5L-52X steel pipes has gained considerable applications due to their high strength and toughness at low temperatures. Moreover, their good weldability has made it a suitable candidate for FSW process. However, the investigation of microstructural evolution, strength and grain refinement after FSW has still been a challenge.

The main objective of this paper is to deal with the effect of processing parameters on the microstructure of API 5L52X steel after FSW process.

\section{EXPERIMENTAL PROCEDURE}

FSW process was carried out on API 5L-X52 steel specimens; chemical composition and mechanical properties of which are given in Tables 1 and 2 . Specimens were cut and polished to $300 \times 50 \times 2 \mathrm{~mm}$ before being FSWed using a WC-3Co tool. Shoulder size, pin diameter and height were 16,4 and $1.8 \mathrm{~mm}$ respectively (Figure 1). Specimens were firmly clamped in a fixture. The linear speed of the tool was kept constant at $100 \mathrm{~mm} / \mathrm{min}$ but the tool rotational speed was in the range of 400-800 rpm. Three specimens were prepared for each processing conditions. The welding tools were trimmed after travelling distance of $270 \mathrm{~mm}$. 
Table 1. Chemical composition of API 5L- X52 steel.

\begin{tabular}{c|ccccccccccc}
\hline $\begin{array}{c}\text { Chemical composition } \\
(\text { (w. \% })\end{array}$ & C & Nn & Si & S & P & Al & Ti & No & Cr & Cu & V \\
\hline API.5L & 0.126 & 1.009 & 0.218 & 0.005 & 0.01 & 0.036 & 0.002 & 0.002 & 0.01 & 0.029 & 0.005 \\
\hline
\end{tabular}

Table 2. Mechanical properties of API 5L- X52 steel.

\begin{tabular}{ccccc}
\hline & Yield strength(MPa) & $\begin{array}{c}\text { Ulimate tensile } \\
\text { strengh }(\mathrm{MPa})\end{array}$ & $\begin{array}{c}\text { Fracture strength } \\
(\mathrm{MPa})\end{array}$ & Elongation\% \\
\hline Mechanical properties & 346 & 470 & 426 & 46 \\
\hline
\end{tabular}

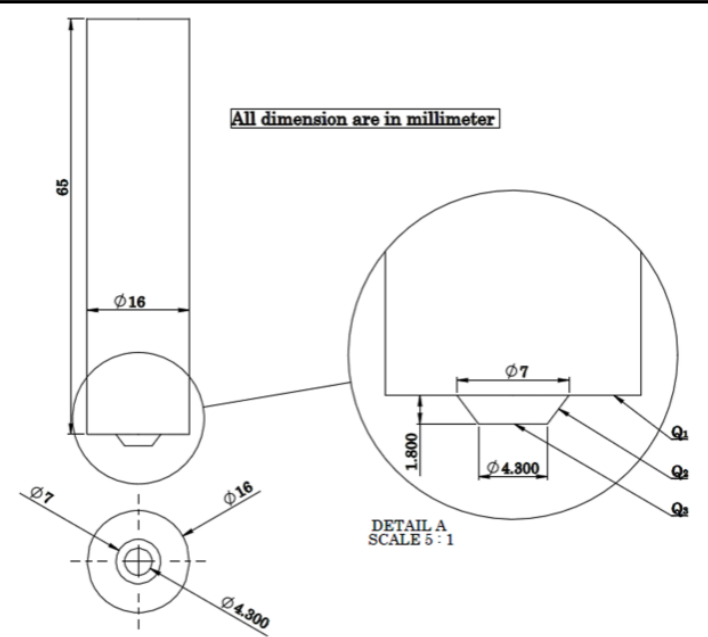

Figure 1. Schematic representation of welding tool.

The temperature of the weld was monitored using a $\mathrm{K}$ type thermocouple (Figure 2).

In order to obtain precise results the thermocouples were placed as close to the welding zone as possible.

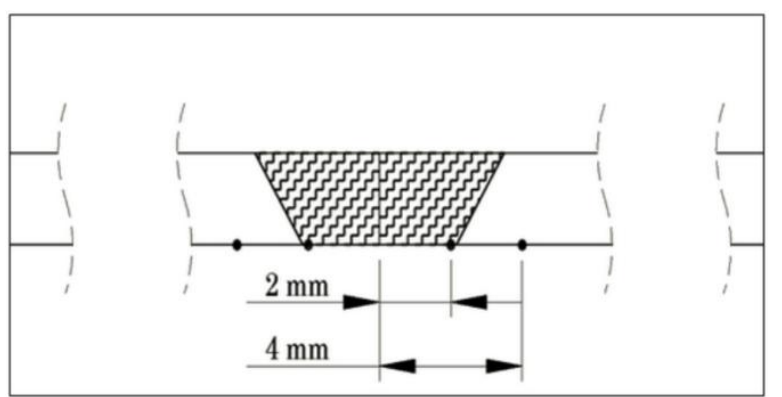

Figure 2.Schematic of location of thermocouples

The microstructure of the welded zone was investigated using optical and scanning electron microscopes.

The specimens were etched in $2 \%$ Nital after being polished, to facilitate grain and phase investigations [21, 22]. Optical microscope Nikon Stereo Zoom and SEM type PHILIPS XL30 were used in the study. The Clemex software was used for image analysis. Phase investigations were carried out using Bruker-D8 advance defractometer in the range of 10 to 90 degrees.

Brinnel hardness testing was performed under a load of 100 kilograms to extract hardness profiles [23]. Yield and ultimate tensile strengths together with the elongation of the welded joints were also studied with due attention to their corresponding heat affected zone (HAZ), stir zone (SZ) and thermomechanically affected zone (TMAZ), according to ASTM standard E8 [24]. (Figure 3)

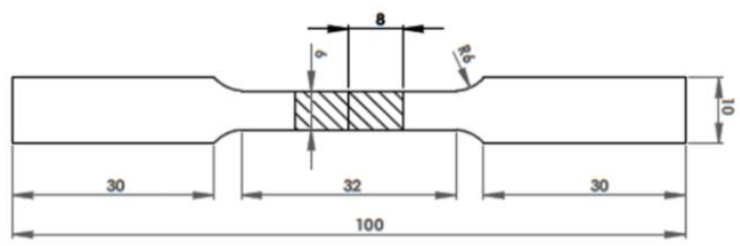

Figure 3. Dimensions of specimens for mechanical testing. (All dimensions are in ' $\mathrm{mm}$ ')

Figure 4 presents a schematic of the impact test specimens as stated by standard ASTM E23-06 [25].
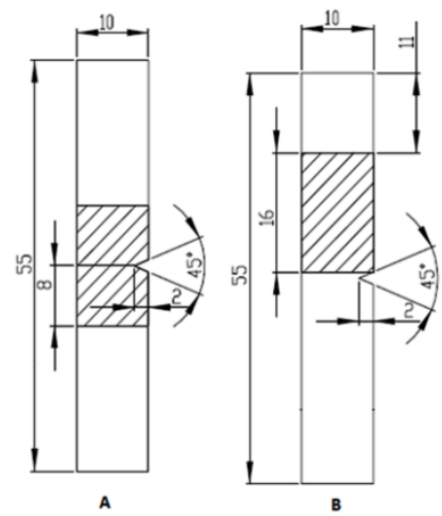

Figure 4. Dimension of specimens for impact test. A: Notch at weld center B: Notch at HAZ. (All dimensions are in ' $m m$ ')

\section{III.RESULTS AND DISCUSSION}

\section{A. Thermal History}

Paying careful attention to the amount of heat input has a great impact on microstructure, phase transformation, and distortions. Schmidt et al. [26] suggested the following relationship to determine the amount of heat generated during FSW process.

$$
Q_{\text {total }}=\frac{2}{3} \pi \tau_{\text {contact }} \omega_{r}\left(r_{s}^{3}+3 r_{p}^{2} H_{p}\right)
$$

Where Q (W) is the heat input, $\omega_{\mathrm{r}}$ is the angular velocity of the tool $\left(\frac{\mathrm{rad}}{\mathrm{s}}\right), \mathrm{r}(\mathrm{m})$ is the radius, $\tau_{\text {contact }}$ is the shear stress $(\mathrm{Pa})$, and $\mathrm{d}_{\mathrm{A}}$ is the surface area $\left(\mathrm{m}^{2}\right)$. Other researches have made a more detailed study on the heat input in which $r_{s}, r_{p}$ and $H_{p}$ is shoulder radius, pin radius and pin height $[26,27]$ as follows:

$$
\begin{aligned}
& q_{1}=\frac{Q_{1}}{Q_{\text {total }}}=\frac{r_{s}^{3}-r_{p}^{3}}{\left(r_{s}^{3}+3 r_{p}^{2} H_{p}\right)}=0.959 \\
& q_{2}=\frac{Q_{2}}{Q_{\text {total }}}=\frac{3 r_{p}^{2} H_{p}}{\left(r_{s}^{3}+3 r_{p}^{2} H_{p}\right)}=0.023 \\
& q_{3}=\frac{Q_{3}}{Q_{\text {total }}}=\frac{r_{p}^{3}}{\left(r_{s}^{3}+3 r_{p}^{2} H_{p}\right)}=0.0189
\end{aligned}
$$

Where $\mathrm{q}_{1}, \mathrm{q}_{2}$ and $\mathrm{q}_{3}$ are the heat input due to shoulder, pin tip and the pin root respectively. As can be seen in the above calculations, heat generated from the shoulder has a greater magnitude compared with that of other sources. Similar analogy has been reported by researchers [28, 29]. Figure 5, illustrates the temperature variations along a welded metal. It can be observed that the temperature of the process is related to the rotational speed $(\omega)$ and the linear velocity $(\mathrm{V})$ of the tool. 


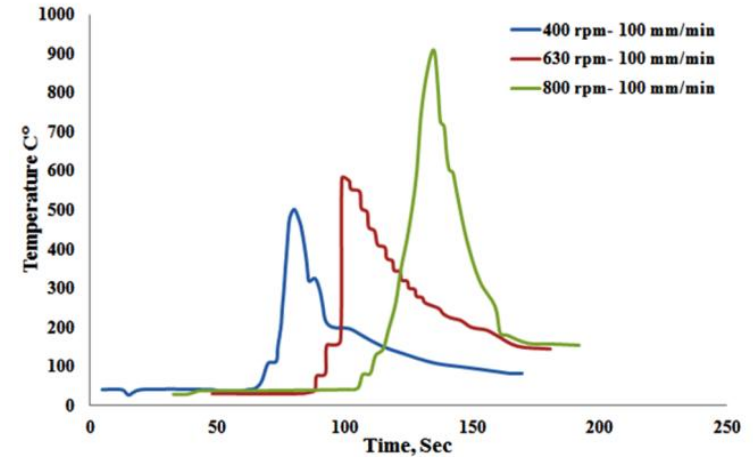

Figure 5.Thermal profiles measured at the rotation speed of 400rpm, $630 \mathrm{rpm}$ and 800rpm with welding speed of $100 \mathrm{~mm} / \mathrm{min}$ in $2 \mathrm{~mm}$ distance from centreline.

Arbegast [30] concentrated on the welding temperature and proposed the following formula;

$$
\frac{T}{T_{m}}=K\left[\frac{\omega^{2}}{v \cdot 10^{4}}\right]^{\alpha}
$$

Where $(\mathrm{T})$ is the welding temperature, $\left(\mathrm{T}_{\mathrm{m}}\right)$ the melting point of the alloy, $(\alpha)$ and $(\mathrm{K})$ are constants. The amount of $\alpha$ and $\mathrm{K}$ have been reported in the range of 0.04-0.06 and $0.65-0.75$ respectively.

Arbegast's Equation can be used to predict a favourable condition for a sound defect free weld. The role of process parameters on heat input has been investigated by Frigaard et al [31].

$$
Q=4 / 3 \cdot \frac{10^{-3}}{60} \cdot \pi^{2} \cdot \mu \cdot P \cdot \frac{\omega}{v} \cdot R^{3}
$$

Where $\mathrm{Q}$ is the heat input per unit length of the weld, $\mu$ the friction coefficient, $\mathrm{P}$ the pressure, $\omega$ the rotational speed, $\mathrm{V}$ the linear velocity, and $\mathrm{R}$ is the shoulder radius. It can be deduced from the formula that at low linear velocity the heat input increases. Moreover, there is a direct relationship between the rotational speed of the tool and heat input. The maximum temperature of the workpieces after FSW was measured $1250 \mathrm{C}$ in the nugget zone.

\section{B. Microstructure}

A typical FSW specimen exhibits four distinct zones, namely the stir zone (SZ), thermo mechanically affected zone (TMAZ), and heat affected zone (HAZ) and the base metal (BM) (Figure 6).

According to Equation 1, the temperature at $800 \mathrm{rpm}$ can reach 1150 degrees Celsius, which is below the melting point of steel. The etched microstructure revealed elongated grains in the base metal. The grain size was in the order of 40 microns consisting mainly ferrite with about 10 percent pearlite. The heat affected zone can clearly be seen with rather coarse grains adjacent to TMAZ.

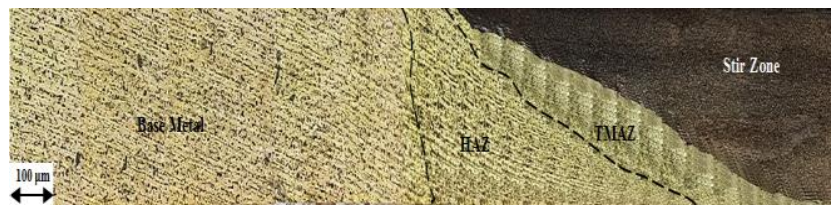

Figure 6. Schematic of microstructure of weld region $(630$ $\mathrm{rpm}-100 \mathrm{~mm} / \mathrm{min}$ )
The low heat input in the FSW process compared to other conventional welding processes results in smaller HAZ (Figure 6).

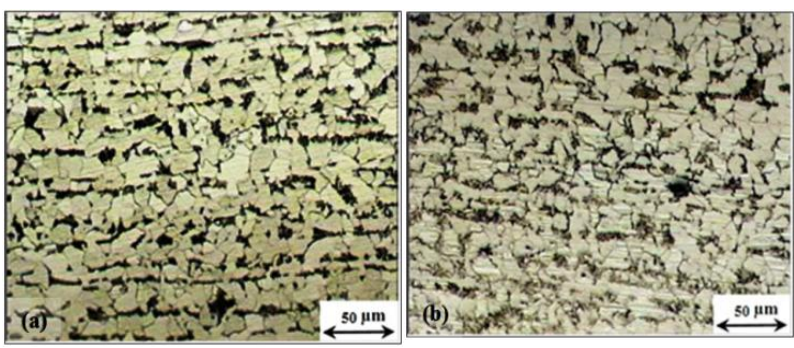

Figure 7.OM micrographs of the API 5L-X52 steel HAZ. a) Partial grain refined HAZ. b) Fully grain refined HAZ. (630 rpm-100 mm/min)

According to $\mathrm{Fe}-\mathrm{C}$ phase diagram, the $\mathrm{HAZ}$ temperature constitutes $A_{1}$ and $A_{3}$ critical lines having ferrite and austenite dual phase. It has been reported that the as FSW proceeds, the pearlite islands transform to austenite which extend into the primary ferrite above the A1 critical line. The net effect is formation of fine pearlite during cooling. However, ferrite mean grain size remained constant at 16 micron (Figure 7a).

Figure $7 \mathrm{~b}$ illustrates that fine grains have developed in the HAZ, which comprise small ferrite and austenite grains.

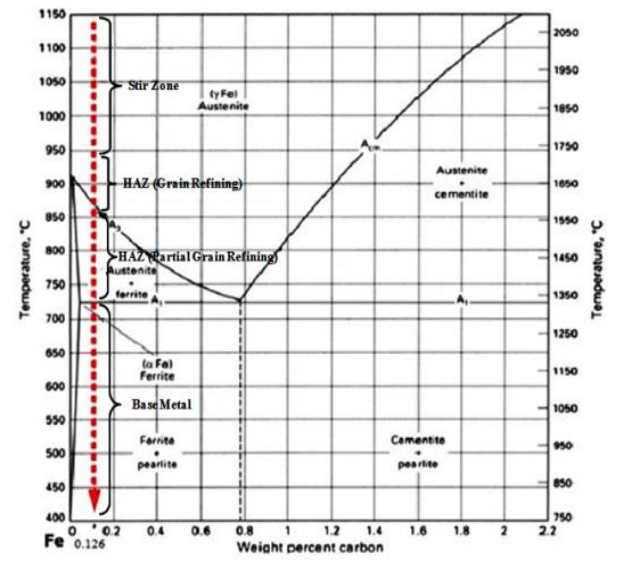

Figure $8 . \mathrm{Fe}-\mathrm{C}$ phase diagram and various transformations with temperature.

The average grain size was about 9 microns in this region (Table 3). This phenomenon might stem from the fact that the peak temperature has passed beyond the $\mathrm{A}_{3}$ critical line, accelerating the nucleation of austenite grains, which in turn transform to ferrite and pearlite phases during cooling (Figure 8).

Table 3.Grain size variations in fully and partial grain refined HAZ.

\begin{tabular}{lcc}
\hline Welding condition & $\begin{array}{c}\text { Mean grain size } \\
\text { (partial grain refinement) } \mu \mathrm{m}\end{array}$ & $\begin{array}{c}\text { Mean grain size } \\
\text { (full grain refinement) } \mu \mathrm{m}\end{array}$ \\
\hline $100 \mathrm{~mm} / \mathrm{min}-400 \mathrm{rpm}$ & 16.9 & 7.74 \\
$100 \mathrm{~mm} / \mathrm{min}-630 \mathrm{rpm}$ & 17.6 & 9.91 \\
$100 \mathrm{~mm} / \mathrm{min}-800 \mathrm{rpm}$ & 20.9 & 10.79 \\
\hline
\end{tabular}

Low cooling rate at $800 \mathrm{rpm}$ may have provided more time for grain growth of austenite grains above $A_{3}$ critical line. The net result is growth of ferrite and pearlite grains. However it is difficult to differentiate between the grains 


\section{International Advanced Research Journal in Science, Engineering and Technology}

Vol. 2, Issue 11, November 2015

due to low variations in the heat input. Thus TMAZ could not be clearly seen in the low carbon steels (Figure 9). While the HAZ experiences a heating cycle, the SZ undergoes both thermal cycle and severe plastic deformation simultaneously. The peak temperature in SZ was around 1050 degrees Celsius, which is the austenite phase in API-5L steels.

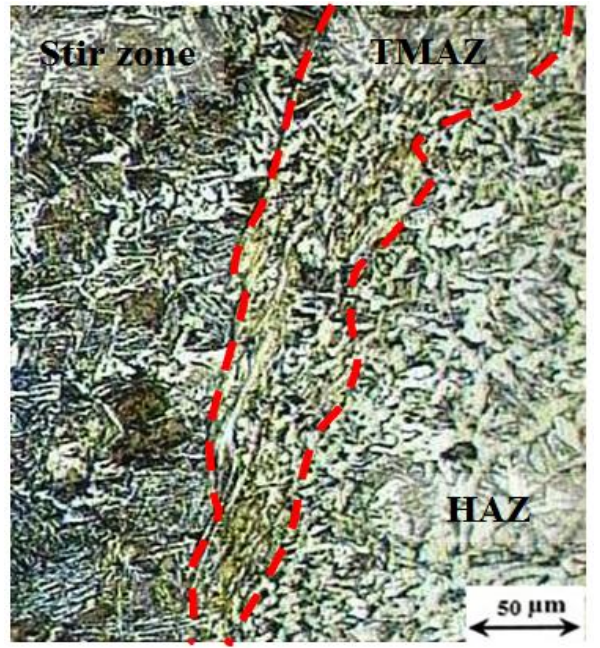

Figure 9.TMAZ microstructure (630 rpm-100 mm/min)

It has been reported that total strain in carbon steels during FSW process is more than $10^{\circ}$ and the strain rate is $10^{2}$ per second [32]. Under such circumstances, recovery in SZ can occur. It appears that recrystallization takes place in API-5L steels at high strain rates. Materials with low stacking fault energy normally undergo discontinuous dynamic recrystallization (DDRX) [33]. Fine austenite grains begin to sprout leaving the matrix with two distinct microstructures after allotropic transformation during cooling, hence, DDRX disappears.

X-ray diffraction patterns of the specimens after FSW are shown in Figure 10. The major peak is related to the ferrite phase. The cementite peak is invisible since the major ferrite overlaps the minor cementite phase. The more welding speed the greater the amount of ferrite due to extensive strain and grain refinement in the SZ.

The white lines in the microstructure are generated as a result of the formation of onion rings in the SZ and depend on the material flow pattern (Fig.11).

Past investigations suggest that onion rings can occur after instantaneous change in the grain size and distribution after severe plastic deformation.

Later investigations revealed that onion rings contain boundaries separating the fine grains from the coarse ones $[34,35]$.

Figures 12 illustrate the microstructure of the SZ of API 5L-X52 steel, which comprises ferrite and pearlite grains. It has been well established that ferrite grains appear in the vicinity of austenite grain boundaries below the $A_{3}$ line. As the temperature drops below the $A_{1}$ line, pearlite grains are formed from the retained austenite in the shape of successive ferrite and cementite layers [36]. Since the temperature in the centre of SZ is higher than that of the edges, pearlite grains begin to nucleate in the centre.

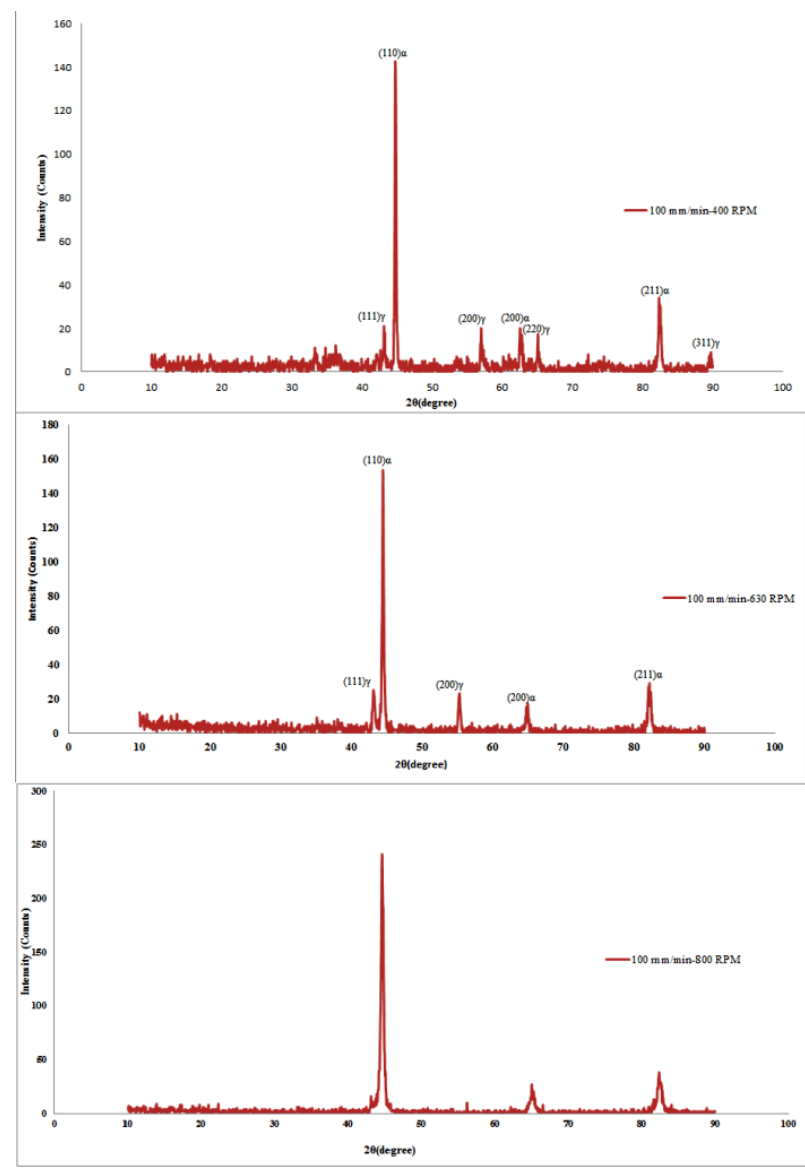

Figure 10. X-ray diffractograms of samples in different welding speeds.
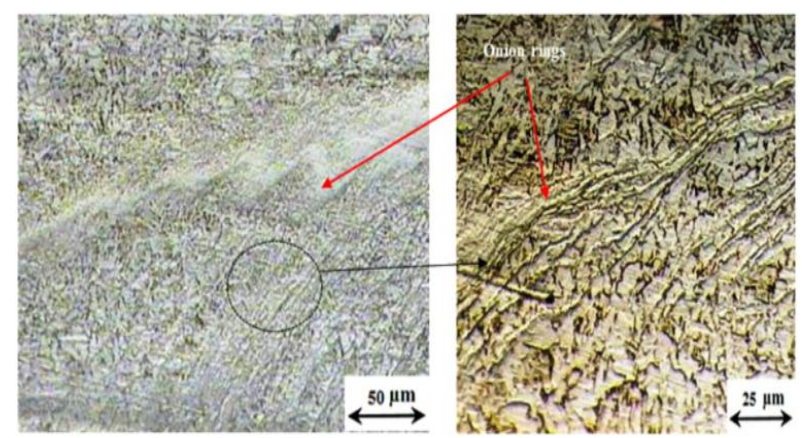

Figure 11. Onion ring in Stir Zone

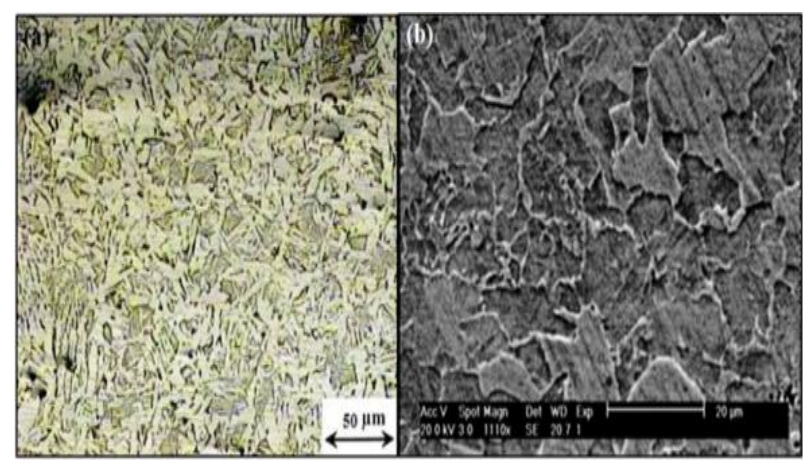

Figure 12. OM and SEM micrographs of the stir zone (630 $\mathrm{rpm}-100 \mathrm{~mm} / \mathrm{min}$ )

Figure 13 depicts a micrograph taken from the edge of SZ showing grain boundary ferrite (PF), widmanstatten-ferrite $(\mathrm{WN})$ and ferrite-cementite (FC) phases. 
Normally, allotromorphic ferrite grains are formed at the austenite grain boundaries at temperatures below $\mathrm{A}_{3}$ critical line, known as grain boundary ferrite. Moreover, widmanstatten ferrite begins to appear as a result of rapid diffusion of carbon atoms across the austenite grain boundaries (Figure 13).

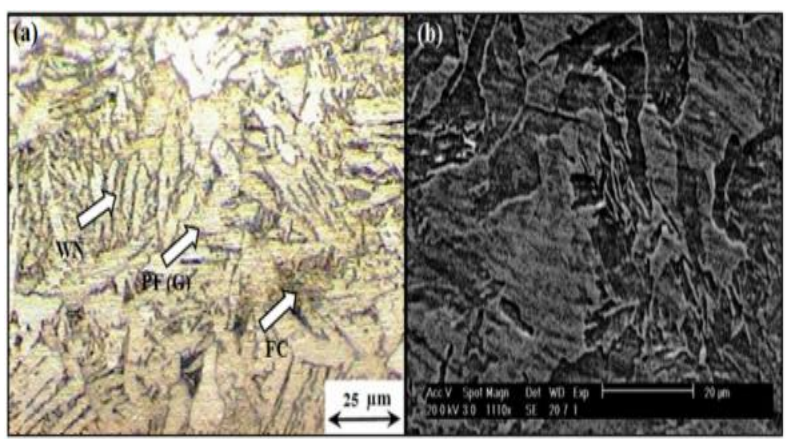

Figure 13. The stir zone in the API 5L-X52 steel showing grain boundary ferrite $(\mathrm{PF})$, widmanstatten ferrite $(\mathrm{WN})$ and ferrite + carbide (FC) microstructure $(800 \mathrm{rpm}-100 \mathrm{~mm} / \mathrm{min})$

The $\mathrm{M}_{\mathrm{s}}$ temperature is about 500 degrees Celsius in low carbon steels. Thus, very fine cementite begins to precipitate from the primary cementite grains.

The Zenner-Hollman parameter which describes strain rate and temperature is given as follows:

$$
Z=\dot{\varepsilon} \exp \left({ }^{Q} / R T\right)
$$

Where $\mathrm{Q}$ and $\mathrm{R}$ are the activation energy and gas constant respectively.

The final grain size of the recrystallized grains is given by Equation 8.

$$
d=(a+b \ln z)^{-1}
$$

Where ' $a$ ' and ' $b$ ' are constants and depend on the material [36]. It is clear that strain rate is directly proportional to rotational speed of the tool. The net effect of the involved parameters may lead to increased ' $Z$ '. The grain size variation in the SZ is shown in Table 4 suggesting no dramatic change in the grain size. The grain size number ' $n$ ' was calculated according to ASTM E11296. [37]

Table 4. Grain size variations in stir zone

\begin{tabular}{cc}
\hline welding condition & mean grain size $(\mu \mathrm{m})$ \\
\hline $400 \mathrm{rpm}-100 \mathrm{~mm} / \mathrm{min}$ & 8.89 \\
$630 \mathrm{rpm}-100 \mathrm{~mm} / \mathrm{min}$ & 6.54 \\
$800 \mathrm{rpm}-100 \mathrm{~mm} / \mathrm{min}$ & 10.04 \\
\hline
\end{tabular}

$$
N=2^{n-1}
$$

Where $\mathrm{N}$ is the number of grains at the magnification of 100 in one square inch and ' $n$ ' is the grain size number. Figure 14 illustrates the grain size number in the SZ at different rotational speeds of the tool.

It can be seen that by changing the rotational speed from 400 to $630 \mathrm{rpm}$, the corresponding grain size umber was raised from 6.54 to 7.18 . However the grain size number dropped to 6.76 at $800 \mathrm{rpm}$. This phenomenon may be attributed to the Zener parameter (Equation 8).

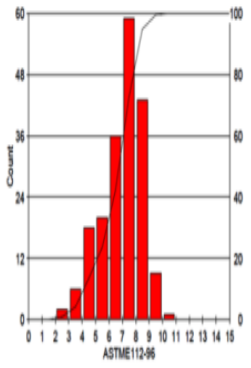

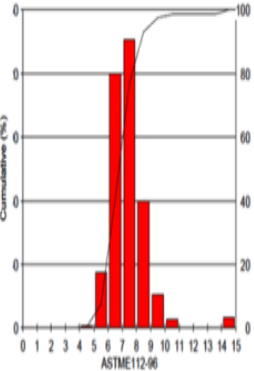

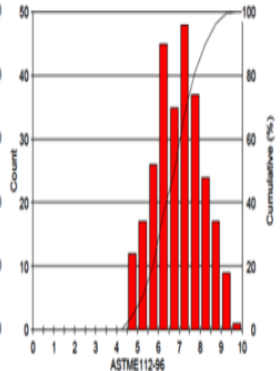

Figure 14.Comparison of the grain size number in the SZ a) $100 \mathrm{~mm} / \mathrm{min}$ - $400 \mathrm{rpm}$. b) $100 \mathrm{~mm} / \mathrm{min}-630 \mathrm{rpm}$.

c) $100 \mathrm{~mm} / \mathrm{min}-800 \mathrm{rpm}$.

The dynamic nature of FSW leads to a temperature gradient overcoming the strain rate and thus, lowering the Zener value. Variations in grain number and grain area at different rotational speeds of the tool are presented in Table 5.

Table 5. Variations in grain number and grain area in SZ.

\begin{tabular}{lcccc}
\hline Welding condition & $\begin{array}{c}\text { Number of } \\
\text { grains }\end{array}$ & $\begin{array}{c}\text { Max. area } \\
\left(\mu \mathrm{m}^{2}\right)\end{array}$ & $\begin{array}{c}\text { min. area } \\
\left(\mu \mathrm{m}^{2}\right)\end{array}$ & $\begin{array}{c}\text { Aver. area } \\
\left(\mu \mathrm{m}^{2}\right)\end{array}$ \\
\hline $100 \mathrm{~mm} / \mathrm{min}-400 \mathrm{rpm}$ & 92 & 7248 & 64 & 1808 \\
\hline $100 \mathrm{~mm} / \mathrm{min}-630 \mathrm{rpm}$ & 144 & 4788 & 4 & 893 \\
\hline $100 \mathrm{~mm} / \mathrm{min}-800 \mathrm{rpm}$ & 107 & 5124 & 116 & 1243 \\
\hline
\end{tabular}

\section{Hardness}

Figure 15 shows a schematic hardness test specimen which were cut to $10 \times 80 \mathrm{~mm}$ in $2.5 \mathrm{~mm}$ increments summing to a total of 29 measurements per specimen.

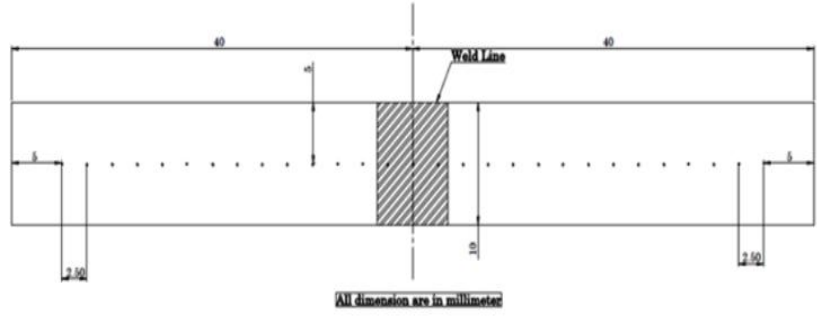

Figure 15. Schematic of specimens for hardness test.

The hardness profile of the weld zone is illustrated in Figure 16, which can be roughly categorized to 4 sections. The base metal had the least average hardness of $68.2 \mathrm{HB}$ due to the existence of ferrite and nearlite nhases.

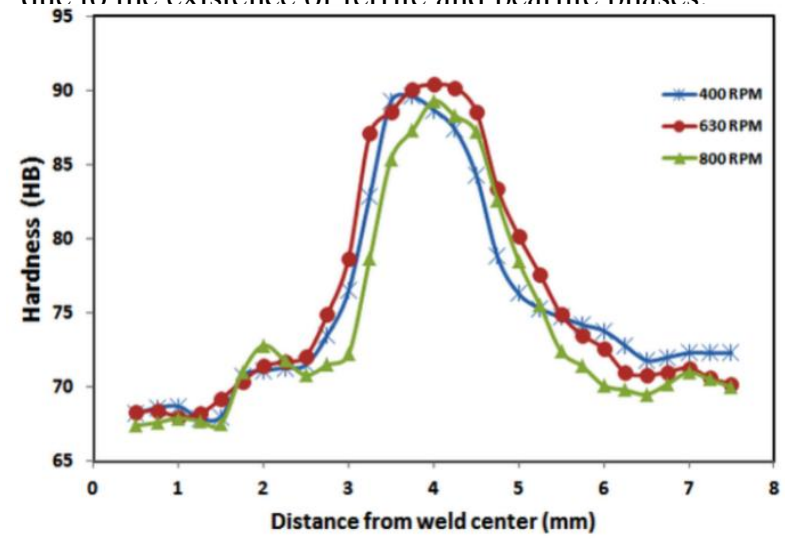


Figure 16.The hardness profile in the cross - section of the welds.

The HAZ was the next which comprised inconsistent grain sizes and an average hardness of $72 \mathrm{HB}$.

The hardness value in the SZ was $93 \mathrm{HB}$ indicating the existence of a great number of dislocations produced due to severe plastic deformation. Comparatively, the hardness of TMAZ was $89 \mathrm{HB}$ being lower than that of SZ, and was in the shape of a narrow band.

The hardness varies with grain size according to HallPetch relationship[38]:

$$
H=H_{0}+K D^{-1 / 2}
$$

Where $\mathrm{H}$ is hardness, $\mathrm{H}_{0}$ relates to the materials hardness with infinite grain size, $\mathrm{K}$ is proportionality constant and $\mathrm{D}$ is grain size, representing the grain boundary as an obstacle to the propagation of deformation.

There was a concurrent increase in the rotational speed and the hardness $(630 \mathrm{rpm})$; however a reverse trend was noticed at a certain point $(800 \mathrm{rpm})$. It appears that at a critical heat input, the predominating mechanism changes from grain refining to grain growth due to low heat loss.

\section{Tensile Strength}

The mechanical properties of the specimens are illustrated in Table 6.

Table 6. Tensile properties of specimens.

\begin{tabular}{cccc}
\hline Welding condition & YS(MPa) & UTS(MPa) & Elongation (\%) \\
\hline $100 \mathrm{~mm} / \mathrm{min}-400 \mathrm{rpm}$ & 357 & 403 & 8 \\
\hline $100 \mathrm{~mm} / \mathrm{min}-630 \mathrm{rpm}$ & 402 & 485 & 12.2 \\
\hline $100 \mathrm{~mm} / \mathrm{min}-800 \mathrm{rpm}$ & 384 & 458 & 10.8 \\
\hline
\end{tabular}

It can be seen that the mechanical properties of the FSWed specimens are higher than that of the base metal. Reduction of grain size in the stir zone (SZ) may have been responsible according to hall petch Equation [39].

$$
\sigma_{0}=\sigma_{i}+k D^{-1 / 2}
$$

Where $\sigma_{0}$ is the yield stress, $\sigma_{i}$ is a materials constant for the starting stress for dislocation movement (or the resistance of the lattice to dislocation motion), $k$ is the strengthening coefficient (a constant specific to each material), and $D$ is the average grain diameter.

Since the grain size in the SZ is smaller the yield and UTS in the SZ are high. In the case of low grain size, the mean path movement of the dislocations are reduced leading to greater dislocation pile up behind the grain boundaries. The net effect would be higher strength and lower elongation in the FSWed specimens.

The tensile properties of the specimens are exhibited in Figure 17. There is a clear jump in strength where the tool rotational speed is raised from 400 to 630 rpm. On the other hand, there is a reduction in strength again at high rotational speed of $800 \mathrm{rpm}$ which can be attributed to the grain coarsening effect at high heat input.

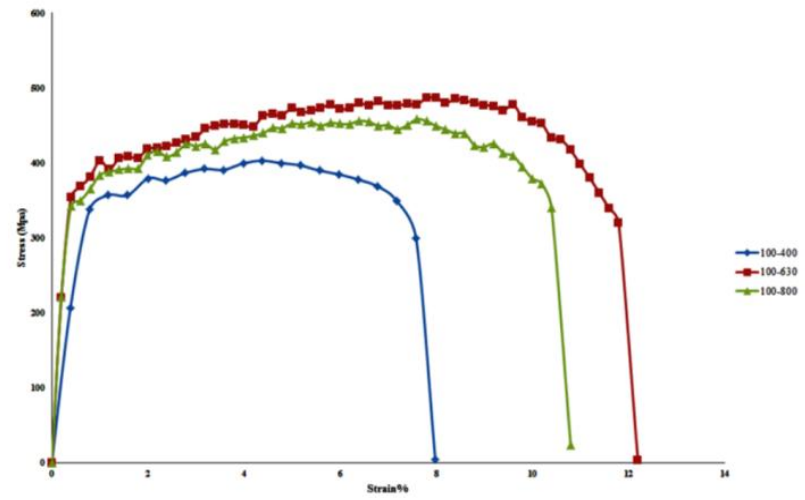

Figure 17.Stress-strain curve at the rotation speed of 400rpm, $630 \mathrm{rpm}$ and 800rpm with welding speed of $100 \mathrm{~mm} / \mathrm{min}$

Moreover, there are favourable conditions for impurities to be introduced from the pin itself. Besides, the turbulent material flow might lead to porosity in the specimens, which themselves act as crack initiation and growth sites (figure 18).

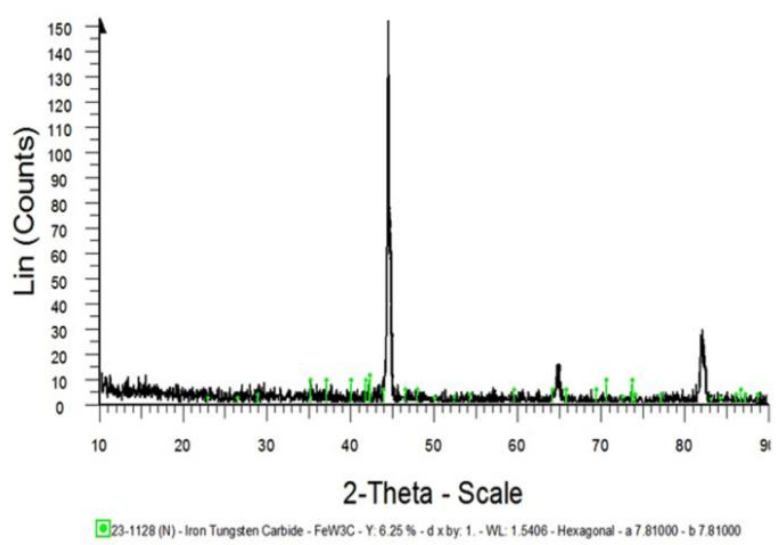

Figure 18. The XRD results from particle at $800 \mathrm{rpm}$

\section{E. Toughness}

Fracture toughness of the specimens was determined from $\mathrm{SZ}$ and HAZ and is presented in Figure 19.

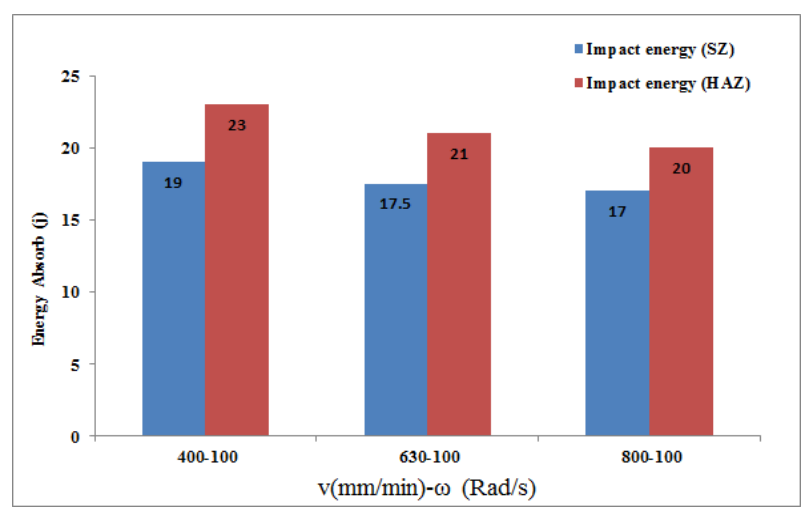

Figure 19. Absorbed charpy impact energy for SZ and HAZ.

Fracture surfaces of SZ shows facets of cleavage fracture and ductile dimples in the HAZ (Figure 20). The impact energy of the samples in the SZ dropped from 19 to 17 Joules at $800 \mathrm{rpm}$. The same 
trend was observed in the HAZ. Greater heat input is considered to be responsible for this phenomenon.

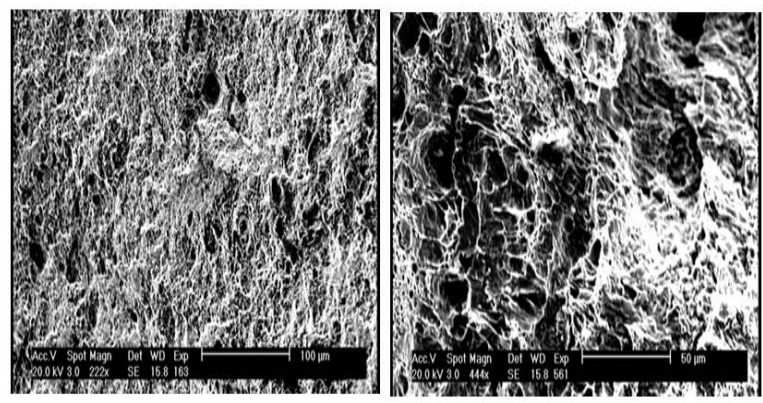

Figure 20. Fracture surface of SZ and HAZ. a)SZ-100mm/min,400rpm b)HAZ-100mm/min,400rpm

\section{IV.CONCLUSION}

1-It can be concluded from this study that, increasing the rotational speed of the tool from $400 \mathrm{rpm}$ to $630 \mathrm{rpm}$ raised the temperature of the stir zone from 480 to 600 degrees. This can be due to the friction at the tool specimen interface, which elevates the heat input and spreads the stir zone.

2-The mean grain size increased from 7.1 (400 $\mathrm{rpm})$, to 8.83 microns $(800 \mathrm{rpm})$ in the stir zone.

3-High rotational speed of the tool led to high hardness values, from 400 to $630 \mathrm{rpm}$, however it dropped to lower values if rotational speed is raised to $800 \mathrm{rpm}$.

4-Friction stir welding can successfully be applied on API 5L-X52 steel. The base metal contained large ferrite and pearlite grains. Hot working led to recrystallization in SZ which upon cooling transformed to widmanstatten ferrite matrix containing martensite islands.

\section{ACKNOWLEDGMENT}

The authors would like to acknowledge the financial support from the Semnan University and managing director of Oghab Afshan Industrial \& Manufacturing Company. The experimental assistance of Mr. F. Kargar and Mr. E. Shahi is greatly appreciated.

\section{REFERENCES}

[1] Hidetoshi Fujii, Ling Cui, Nobuhiro Tsuji, Masakatsu Maeda, Kazuhiro Nakata, Kiyoshi Nogi, Friction stir welding of carbon steels. Materials Science and Engineering A 429 (2006) 50-57.

[2]. Cho JH, Boyce DE, Dawson PR. Modeling strain hardening and texture evolution in friction stir welding of stainless steel. Materials Science and Engineering A 2005;398:146-63.

[3]. Nandan R, Roy GG, Lienert TJ, DebRoy T. Numerical modeling of 3D plastic flow and heat transfer during friction stir welding of stainless steel. Science and Technology of Welding and Joining 2006;11:526-37.

[4]. Lee WB, Lee CY, Chang WS, Yeon YM, Jung SB. Microstructural investigation of friction stir welded pure titanium. Materials Letters 2005; 59:3315-8.

[5]. Sanders DG, Ramulu M, Klock-McCook EJ, Edwards PD, Reynolds AP, Trapp T. Characterization of superplastically formed friction stir weld in titanium 6Al-4V: preliminary results. J Mater Eng Perform 17:187-92.

[6]. K.H. Song, K. Nakata, Effect of precipitation on post-heat-treated Inconel 625 alloy after friction stir welding. Materials \& Design, 31 (2010) 29422947.

[7]. B.K. Jasthi, E.Y. Chen, W.J. Arbegast, M. Heringer, D.R. Bice, S.M Howard, Friction Stir Processing of Cast Inconel 718, in: Friction Stir Welding and Processing VI, John Wiley \& Sons, Inc., 2011, pp. 25-32.

[8]. K.H. Song, K. Nakata. Microstructural and mechanical properties of frictionstir-welded and post-heat-treated Inconel 718 alloy. J. Alloy. Compd., 505 (2010) 144-150.
[9] Hwang B, Kim YM, Lee S, Kim NJ, Ahn SS. Correlation of microstructure and fracture properties of API X70 pipeline steels. Metallurgical and Materials. Transactions A 36 (2005) 725-39.

[10] B. Vargas-Arista, J.M. Hallen, A. Albiter, Effect of artificial aging on the microstructure of weldment on API 5L X-52 steel pipe. Materials Characterization 58 (2007) 721-729.

[11] Sato YS, Yamanoi H, Kokawa H, Furuhara T. Microstructural evolution of ultrahigh carbon steel during friction stir welding. Scripta Mater 57 (2007) 557-60.

[12] Cho H-H, Han HN, Hong S-T, Park J-H, Kwon Y-J, Kim S-H, et al. Microstructural analysis of friction stir welded ferritic stainless steel. Materials Science and Engineering A 528 (2011) 2889-94.

[13] Hoon-Hwe Cho, Suk Hoon Kang, Sung-Hwan Kim, Kyu Hwan Oh, Heung Ju Kim,Woong-Seong Chang, Heung Nam Han. Microstructural evolution in friction stir welding of high-strength linepipe steel. Materials and Design 34 (2012) 258-267.

[14] Y.S.Sato, T.W.Nelson, C.J.Sterling, R.J.Steel, C.O.Pettersson. Microstructure and mechanical properties of friction stir welded SAF 2507 super duplex stainless steel. Materials Science and Engineering A 397 (2005) 376-384.

[15] A. Ozekcin, H. W. Jin, J. Y. Koo, N. V. Bangaru and R. Ayer, A Microstructural Study of Friction Stir Welded Joints of Carbon Steels. International Journal of Offshore and Polar Engineering 14 (2004) 284-288.

[16] Saeid T, Abdollah-zadeh A, Shibayanagi T, Ikeuchi K, AssadiH. On the formation of grain structure during friction stir welding of duplex stainless steel. Materials Science and Engineering A 527 (2010) 6484-8.

17] Mehmet Burak Bilgin, Cemal Meran. The effect of tool rotational and traverse speed on friction stir weldability of AISI 430 ferritic stainless steels. Materials and Design 33 (2012) 376-383.

[18] A.K. Lakshminarayanan, V. Balasubramanian. An assessment of microstructure, hardness, tensile and impact strength of friction stir welded ferritic stainless steel joints. Materials and Design 31 (2010) 4592-4600.

[19] Chung YD, Fujii H, Ueji R, Tsuji N. Friction stir welding of high carbon steel with excellent toughness and ductility. ScriptaMater 63 (2010) 223-6.

[20] Y.F. Sun, H. Fujii, N. Takaki, Y. Okitsu. Microstructure and mechanical properties of mild steel joints prepared by a flat friction stir spot welding technique. Materials and Design 37 (2012) 384-392.

[21] ASM Handbook. Metallography and microstructures, 9th ed. Metals Park Ohio: ASM International; 1992. p. 282-90.

[22] Method of preparation of metallographic specimens, E 3-80, vol. 03.03 . Philadelphia: Annual book of ASTM standards; 1983.

23] Test method for Brinell hardness of metallic materials, E 10, vol. 03.02. Philadelphia: Annual book of ASTM standards: 1984

[24] ASTM International Standard E8M-04. Standard test methods for tension testing of metallic materials.

25] ASTM International Standard E23-06. Standard test methods for notched bar impact testing of metallic materials.

[26] H. Schmidt, J. Hattel, J. Wert, An analytical model for the heat generation in friction stir welding. Modeling and Simulation in Material Science and Engineering. 12 (2004) 143.

27] M.Z.H. Khandkar, J.A. Khan, A.P. Reynolds, Prediction of temperature distribution and thermal history during friction stir welding: input torque based model. Science and Technology of Welding and Joining. 8 (2003) 165.

$28]$ M. Song, R. Kovacevic, Thermal modeling of friction stir welding in a moving coordinate system and its validation, International Journal of Machine Tools \& Manufacture 43 (2003) 605-615.

[29] S. Mandal, K. Williamson, A thermomechanical hot channel approach for friction stir welding,Journal of Materials Processing Technology. 174 (2006) 190-194.

[30] W.J. Arbegast, in: Z. Jin, A. Beaudoin, T.A. Bieler, B. Radhakrishinan (Eds.), Hot Deformation of Aluminum Alloys III, TMS, San Diego, CA, 2003, pp. 313-327.

[31] O. Frigaard, O. Grong, O.T.Midling, Metall. A process model for friction stir welding of age hardening aluminum alloys. Metallurgical and Materials Transactions A32 (2001) 1189-1200.

[32] Lienert TJ, Stellwag WL JR, Grimmett BB, Warke RW. Friction stir welding studies on mild steel. Suppl Weld J Jan 2003: 1s-9s.

[33] Humphreys FJ, Hotherly M. Recrystallization and related annealing phenomena. 2nd ed.New York: Pergamon Press; 1995.

[34]Krishnan KN. On the formation of onion rings in friction stir welds. Materials Science and Engineering A 2002; A327:246-51.

[35]Xie GM, Ma ZY, Geng L. Development of a fine-grained microstructure and the properties of a nugget zone in friction stir welded pure copper. Scripta Materialia 2007;57:73-6.

[36] M. Jafarzadegan, A.H. Feng, A. Abdollah-zadeh, T. Saeid, J. Shen, H. Assadi. Microstructural characterization in dissimilar friction stir welding between 304 stainless steel and st37 steel Materials Charecterization 74(2012)28-41.

37]Test methods for determining average grain size, E 112-96, vol. 03.01. Philadelphia: Annual book of ASTM standards; 2004.

38] Reed-hill Robert E, Abbaschian Reza. Physical metallurgy principles.3rded. PWS Publishing Company; 1994.

[39] Dieter GE. Mechanical metallurgy. London: McGraw-Hill book company; 1988 